\title{
Review
}

\section{Comparison of Experimental Protocols of Physical Exercise for $m d x$ Mice and Duchenne Muscular Dystrophy Patients}

\author{
Janek Hyzewicz ${ }^{\mathrm{a}}$, Urs T. Ruegg ${ }^{\mathrm{b}}$ and Shin'ichi Takeda ${ }^{\mathrm{a}, *}$ \\ ${ }^{a}$ Department of Molecular Therapy, National Institute of Neuroscience, National Center of Neurology and \\ Psychiatry \\ ${ }^{\mathrm{b}}$ University of Geneva, Switzerland
}

\begin{abstract}
.
Duchenne Muscular Dystrophy (DMD) is caused by mutations in the gene coding for dystrophin and leads to muscle degeneration, wheelchair dependence and death by cardiac or respiratory failure. Physical exercise has been proposed as a palliative therapy for DMD to maintain muscle strength and prevent contractures for as long as possible. However, its practice remains controversial because the benefits of training may be counteracted by muscle overuse and damage.

The effects of physical exercise have been investigated in muscles of dystrophin-deficient $m d x$ mice and in patients with DMD. However, a lack of uniformity among protocols limits comparability between studies and translatability of results from animals to humans. In the present review, we summarize and discuss published protocols used to investigate the effects of physical exercise on $m d x$ mice and DMD patients, with the objectives of improving comparability between studies and identifying future research directions.
\end{abstract}

Keywords: Duchenne muscular dystrophy, mice, $m d x$, exercise

$\begin{array}{ll}\text { ABBREVIATIONS } \\ \text { ACC } & \begin{array}{l}\text { Acetyl-CoA carboxylase } \\ \beta-H A D\end{array} \\ \text { DIAPH } & \text { Diaphragm } \\ \text { DMD } & \text { Duchenne muscular dystrophy } \\ \text { EDL } & \text { Extensor digitorum longus } \\ \text { ERK1/2 } & \text { Extracellular signal-regulated } \\ & \text { kinase 1/2 } \\ \text { GAST } & \text { Gastrocnemius muscle } \\ \text { HIF-1 } & \text { Hypoxia-inducible factor-1 } \\ \text { JNK } & \text { c-Jun N-terminal kinase } \\ \text { MAPK } & \text { Mitogen-activated protein kinase } \\ \text { MHC2a } & \text { Myosin heavy chain 2a } \\ \text { NADPH oxidase Nicotinamide adenine } & \text { dinucleotide phosphate-oxidase }\end{array}$

*Correspondence to: Shin'ichi Takeda, Department of Molecular Therapy, National Institute of Neuroscience, National Center of Neurology and Psychiatry, 4-1-1 Ogawa-higashi, Kodaira, Tokyo 187-8502, Japan. Tel.: +81 42346 1720; Fax: +81 42346 1750; E-mail: takeda@ncnp.go.jp.

$\begin{array}{ll}\text { PGC-1 } \alpha & \begin{array}{r}\text { Peroxisome proliferator-activated } \\ \text { receptor gamma coactivator } 1 \alpha \\ \text { Peroxisome proliferator-activated } \\ \text { receptor gamma }\end{array} \\ \text { QUAD } & \begin{array}{l}\text { Quadriceps muscle } \\ \text { Reactive oxygen species }\end{array} \\ \text { SDH } & \text { L-Sorbose 1-dehydrogenase } \\ \text { Sirt } 1 & \text { Sirtuin } 1\end{array}$

\section{INTRODUCTION}

Duchenne muscular dystrophy (DMD) is an Xlinked muscular disease caused by mutations in the $D M D$ gene, which codes for dystrophin, a cytoskeletal scaffolding protein important in signalling and muscle stability. An absence of dystrophin results in muscle degeneration and death by cardiac or respiratory failure. Symptoms usually appear in boys at 2-5 years of age, manifesting as difficulty standing unaided. As muscle wasting progresses, patients 
experience increasing difficulty in performing daily activities, become wheelchair-dependent between 11 and 13 years of age [1], and die before age 30 [2].

Therapeutic approaches for DMD include reducing inflammatory symptoms with glucocorticoids [3], correcting scoliosis by surgical intervention [4] and aiding respiratory function using mechanical ventilation [5]. Recently, restoration of dystrophin expression has been achieved by ribosomal readthrough of premature stop codons [6] and exon-skipping therapy [7].

Regular physical exercise stimulates muscle protein synthesis and mitochondrial biogenesis [8]. Exercise has therefore been proposed as treatment for DMD, to maintain muscle strength and prevent contractures $[9,10]$; however, this recommendation has not been unanimously accepted because exercise might damage dystrophic muscles [11]. The five mechanisms rendering dystrophin-deficient muscles vulnerable to exercise (reviewed elsewhere [12]) are the weakening of the sarcolemma, increased calcium influx and oxidative stress, recurrent muscle ischemia and aberrant signalling to surrounding tissues such as nerves or cells of the immune system. A mechanistic basis for exercise intolerance [13] and recommendations for the management of DMD $[9,14]$ have also been reviewed. The lack of uniformity between protocols for exercise of dystrophin-deficient muscles, however, has been pointed out [15], but not reviewed.

Here, we summarize and discuss studies addressing physical training in the context of DMD. We focus on articles describing the effects of exercise in dystrophindeficient $m d x$ mice and in patients with DMD (Fig. 1A).

\section{EXPERIMENTAL PROCEDURES FOR THE STUDY OF EXERCISE IN MDX MICE}

\section{A murine model for DMD: The mdx mouse}

The dystrophin-deficient $m d x$ mouse is the most common animal model for DMD. This mutant bears a spontaneous nonsense mutation in exon 23 of the dystrophin gene [16]. Its phenotype is mild compared to the symptoms of DMD in patients. This difference in disease severity between mice and humans arises from differences in size, mechanical loading and lifespan $[17,18]$. First, the size difference between mice and humans is 2000-3000 folds. According to the square/cube rule, the mechanical stress experienced by an organism increases with the cube of the linear size; therefore, the difference in mechanical stress experienced by mice and humans is not linear but exponential [18]. Second, humans have a bipedal posture, mean- ing that the body weight is distributed between the lower limbs and the backbone [17], rather than across four limbs. Third, the difference in lifespan means that humans endure more degeneration-regeneration cycles than mice, resulting in extended muscle deterioration [17].

Compared to DMD patients, $m d x$ mice recover from the progressive muscle wasting and show much less accumulation of connective and adipose tissue. The necrotic process persists throughout their life, but the regenerative capacity does not decline until an advanced age ( $>65$ weeks) $[19,20]$. These differences must be considered in investigations of physical exercise on dystrophic muscle across species.

\section{Exercise studies in mdx mice}

A literature search in PubMed, using the keywords " $m d x$ mice" and "exercise" was performed on 25 May 2015. A total of 175 articles were examined, of which 57 investigated the effects of physical exercise, and were selected to form the basis of this part of the review. Of these studies, 37 reported only the negative effects of physical exercise, 15 only beneficial effects, and 5 both negative and positive effects. Studies were classified according to experimental protocol and are listed in Table 1.

\section{The purpose of exercise studies in mdx mice}

Physical training of $m d x$ mice served three purposes: assessing the physical capacities of the mice; investigating the effects of training on dystrophic muscles; worsening the phenotype before assessing the effects of a drug (Fig. 1B). Depending on the study goals, researchers used acute exercise protocols to reveal immediate effects (Table 1A), or chronic protocols to study long term effects (Table 1B). The mildest methods used included swimming, voluntary wheel running, rotarod or low-speed treadmill ( $<9 \mathrm{~m} / \mathrm{min}$ ). The hardest ones employed high-speed treadmill $(>12 \mathrm{~m} / \mathrm{min})$ or downhill running. Further variables included the age of the mice and training duration. Voluntary and brief ( $<30 \mathrm{~min}$ per session) exercise of young mice $(<8$ weeks old) was defined as low intensity training $[30,59]$, whereas exercise of older mice, or under intensive or prolonged conditions (>30 min), was defined as high intensity training [63].

\section{Assessment of the physical capacities of mdx mice}

Measuring the running capabilities of $m d x$ mice using voluntary wheel or downhill running is a simple 
A

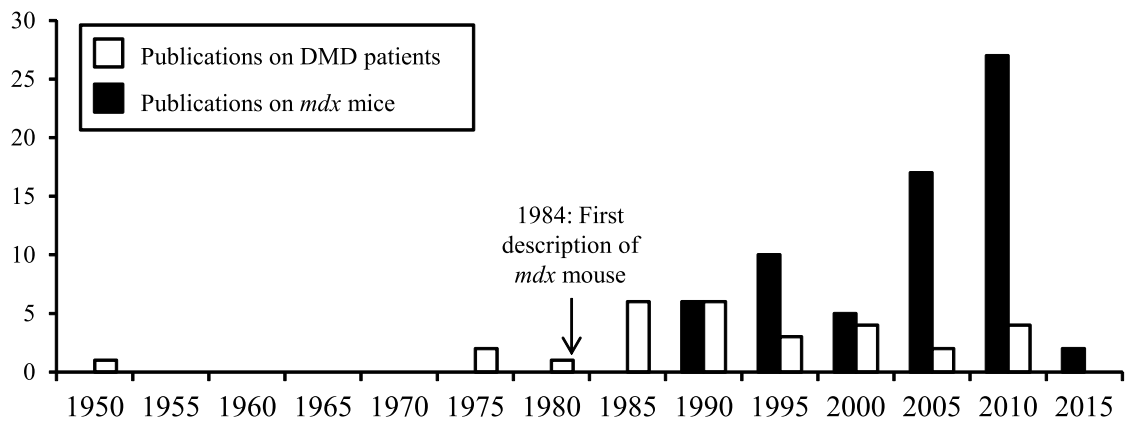

B

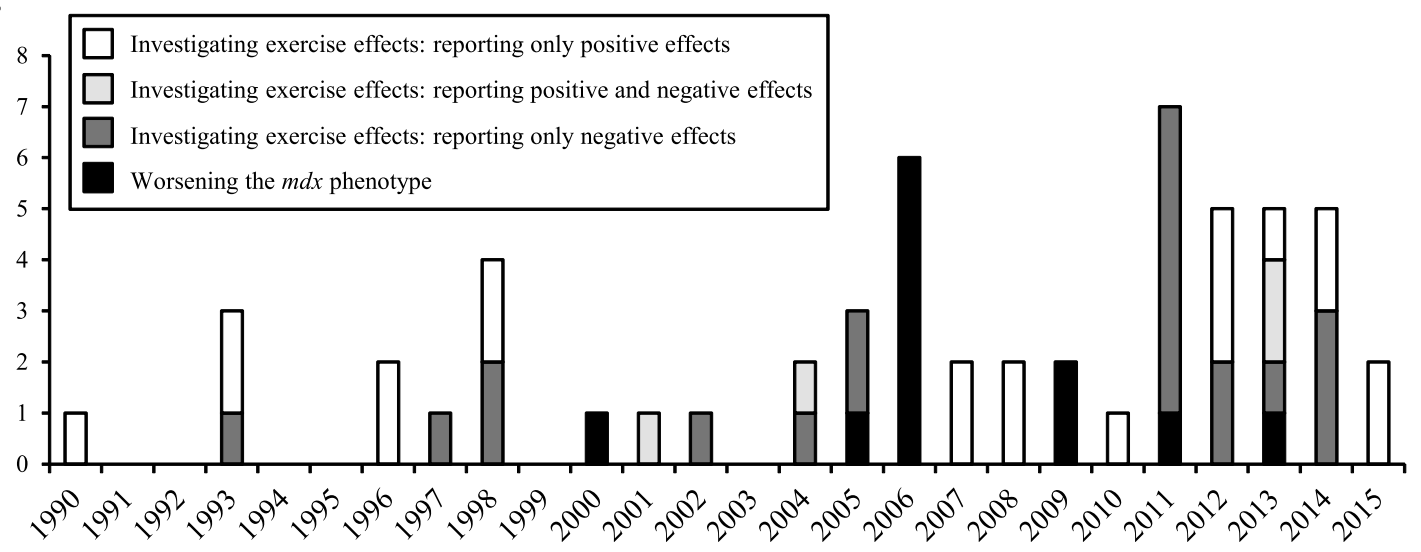

Fig. 1. Frequency of publications reporting the effects of physical exercise in $m d x$ mice and DMD patients. (A) Publications describing the effects of physical exercise on $m d x$ mice and DMD patients per 5 years. (B) Publications describing the effects of physical exercise on $m d x$ mice per year, as a function of research objective.

way to assess their physical abilities. All studies using voluntary wheel running followed the same protocol, namely measuring the total running distance. High inter-individual variability was reported: 4-week-old $m d x$ mice ran 0.5 [38] to $9 \mathrm{~km}$ [36] per day; 6-week-old mice ran $2 \mathrm{~km} /$ day [36], while 10 -week-old mice ran $0.03 \pm 0.005$ to $4.48 \pm 0.96 \mathrm{~km} /$ day [49]. Performance of $m d x$ mice peaked at 8 weeks of age (5.8 [39] to $9 \mathrm{~km}$ [36] per day) and decreased to $2.6 \mathrm{~km} /$ day at 10 weeks [39] or to $5 \mathrm{~km} /$ day at 14 weeks of age [36]. In consequence, a large number of animals should be used when performing experiments with $m d x$ mice. The downhill exercise study [76] adapted the 6 minute walking test, used for patients with DMD, to allow comparison of performance between 10-week-old wild type and $m d x$ mice. Results show that wild type mice run an average of $500 \mathrm{~m}$ in 6 minutes, but $m d x$ mice run only $300 \mathrm{~m}$.

Measuring ex vivo the properties of specific muscles is another way to assess physical capacity in mice. However, muscle type and choice of protocol varied too much between studies to allow comparison (Table 1).
The parameters assessed after voluntary wheel running included tetanic stress and stiffness of the extensor digitorum longus [36], grip strength and specific tetanic force of the soleus [38], maximal isometric torque and fatigue resistance of the plantar flexor [39] or specific and absolute maximal force of the tibialis anterior muscle [41]. Overall experiments reported that phenotype of hind limb and diaphragm of mdx mice improved when training began before 7 weeks old [45], but worsened if exercise began later period [47]. However, worsening of heart phenotype was observed when training started at 4 weeks old mdx mice [41] In spite of these general considerations, important differences in outcome can be observed between the studies, corroborating the need for a common protocol for measurements in individual muscles after exercise.

Different muscles in $m d x$ mice, such as the hindlimb muscles or the diaphragm, are not equally affected by an absence of dystrophin; for example, hindlimb muscles show more necrotic events than the diaphragm, but less fibrosis, following regeneration [78]. Conse- 
Table 1

Effects of physical exercise on $m d x$ mice

\begin{tabular}{|c|c|c|c|c|}
\hline $\begin{array}{l}\text { 1.A Acute exercise } \\
\text { Age }\end{array}$ & Period & Protocol $^{\mathrm{a}}$ & Effects & Reference \\
\hline \multicolumn{5}{|l|}{ Swimming exercise } \\
\hline 4 weeks & 1 time & $20 \min$ & $\begin{array}{l}\text { Mol. } \uparrow \text { Membrane } \\
\text { breakdown in TA }\end{array}$ & $\begin{array}{l}\text { Bouchentouf et al., } \\
2006[21]\end{array}$ \\
\hline \multicolumn{5}{|l|}{ Voluntary running } \\
\hline 4 weeks & 24 hours & At will & $\begin{array}{l}\text { Mol. } \uparrow \text { Membrane leak in } \\
Q U A, G A S T, T A \text { and DIA }\end{array}$ & $\begin{array}{l}\text { Archer et al., } 2006 \\
\text { [22] }\end{array}$ \\
\hline 12 weeks & 16 hours & At will & $\begin{array}{l}\text { Mol. } \uparrow \text { Myofiber apoptotic } \\
\text { nuclei; } \uparrow \text { Apoptosis of } \\
\text { endothelial cells; } \downarrow \\
\text { Expression of Bcl-2; } \\
\uparrow \text { Expression of Bax, Fas, } \\
\text { ICE-family and ubiquitin in } \\
\text { TA }\end{array}$ & $\begin{array}{l}\text { Podhorska-Okolow et } \\
\text { al., } 1998 \text { [23] }\end{array}$ \\
\hline \multicolumn{5}{|l|}{ Treadmill running } \\
\hline 12 weeks & 1 time & $30 \mathrm{~min}, \mathbf{1 2} \mathrm{m} / \mathbf{m i n}$ & $\begin{array}{l}\text { Clin. } \uparrow \text { Serum Creatine } \\
\text { Kinase } \\
\text { Mol. } \uparrow \text { Necrosis; } \uparrow \text { Thiol } \\
\text { oxidation; } \uparrow I L-6 \text { mRNA in } \\
\text { QUA }\end{array}$ & Terrill et al., 2011 [24] \\
\hline \multicolumn{5}{|l|}{ Downhill running } \\
\hline 7 weeks & 1 time & $10^{\circ}: 90 \mathrm{~min}, \mathbf{8}-\mathbf{1 6} \mathbf{~ m} / \mathbf{m i n}$ & $\begin{array}{l}\text { Mol. } \uparrow \text { Membrane } \\
\text { breakdown in recto femoris }\end{array}$ & $\begin{array}{l}\text { Quinlan et al., } 2006 \\
\text { [25] }\end{array}$ \\
\hline $7-10$ weeks & 1 time & $17^{\circ}: 45 \mathrm{~min}, 10 \mathrm{~m} / \mathbf{m i n}$ & $\begin{array}{l}\text { Clin. } \downarrow \text { Isometric force of } \\
\text { EDL } \\
\text { Mol. } \uparrow \text { Membrane } \\
\text { breakdown in EDL }\end{array}$ & $\begin{array}{l}\text { Whitehead et al., } 2006 \\
\text { [26] }\end{array}$ \\
\hline 12 weeks & 1 time & $16^{\circ}: 5 \mathrm{~min}, \mathbf{0 , 6} \mathbf{~ m} / \mathrm{min}$ & $\begin{array}{l}\text { Mol. } \downarrow \text { Expression of FGF in } \\
\text { triceps muscle }\end{array}$ & $\begin{array}{l}\text { Clarke et al., } 1993 \\
\text { [27] }\end{array}$ \\
\hline $32-56$ weeks & 1 time & $16^{\circ}: 5 \mathrm{~min}, \mathbf{1 0} \mathrm{m} / \mathrm{min}$ & $\begin{array}{l}\text { Clin. } \uparrow \text { Serum Creatine } \\
\text { kinase level } 1 \text { hour after } \\
\text { exercise }\end{array}$ & $\begin{array}{l}\text { Vilquin et al., } 1998 \\
\text { [28] }\end{array}$ \\
\hline 60 weeks & 1 time & $14^{\circ}: 45 \mathrm{~min}, \mathbf{1 0} \mathrm{m} / \mathbf{m i n}$ & $\begin{array}{l}\text { Clin. } \uparrow \text { Transverse relaxation } \\
\text { time constant }(T 2) \text { in lower } \\
\text { hind limbs }\end{array}$ & $\begin{array}{l}\text { Mathur et al., } 2011 \\
{[29]}\end{array}$ \\
\hline \multicolumn{5}{|l|}{ 1.B Chronic exercise } \\
\hline $\begin{array}{l}\text { Age } \\
\text { Swimming exercise }\end{array}$ & Period & Protocol $^{\mathrm{a}}$ & Effects & Reference \\
\hline 4 weeks & 4 weeks & $30 \mathrm{~min}$ & Clin. $\uparrow$ Grip strength & $\begin{array}{l}\text { Hyzewicz et., } 2015 \\
{[30]}\end{array}$ \\
\hline & & & $\begin{array}{l}\text { Mol. } \downarrow \text { Carbonylation and } \uparrow \\
\text { Expression of proteins of } \\
\text { contraction and energy } \\
\text { metabolism; } \uparrow \text { Expression of } \\
\text { slow and fast type Troponin T } \\
\text { and Myosin binding protein C } \\
\text { in GAST }\end{array}$ & \\
\hline 4 weeks & 56 weeks & $30 \mathrm{~min}$ & Clin. $\downarrow$ Fatiguability of EDL & $\begin{array}{l}\text { Wineinger et al., } 1998 \\
\text { [31] }\end{array}$ \\
\hline 5 weeks & 15 weeks & $5 \mathrm{~min}+5 \mathrm{~min} /$ day to 2 hour & $\begin{array}{l}\text { Mol. } \downarrow \text { Sensitivity of soleus } \\
\text { to } \mathrm{Ca}^{2+} \text { and } \mathrm{Sr}^{2+} \text { in EDL }\end{array}$ & Lynch et al., 1993 [32] \\
\hline 5 weeks & 15 weeks & $5 \mathrm{~min}+5 \mathrm{~min} /$ day to 2 hour & $\begin{array}{l}\text { Clin. } \uparrow \text { Tension, relaxation } \\
\text { and fatigue resistance of } \\
\text { soleus and EDL } \\
\text { Mol. } \uparrow \text { Fiber I type in EDL }\end{array}$ & Hayes et al., 1993 [33] \\
\hline $6-8$ weeks & 1 week & $30 \mathrm{~min}$ & $\begin{array}{l}\text { Mol. } \uparrow \text { Muscle hypoxia in } \\
\text { GAST and TA }\end{array}$ & $\begin{array}{l}\text { Matsakas et al., } 2013 \\
{[34]}\end{array}$ \\
\hline 96 weeks & 10 weeks & Until exhaustion & $\begin{array}{l}\text { Clin. } \uparrow \text { Relative tetanic } \\
\text { tension of soleus and EDL }\end{array}$ & Hayes et al., 1998 [35] \\
\hline Age & Period & Protocol $^{\mathrm{a}}$ & Effects & Reference \\
\hline
\end{tabular}


Table 1

(continued)

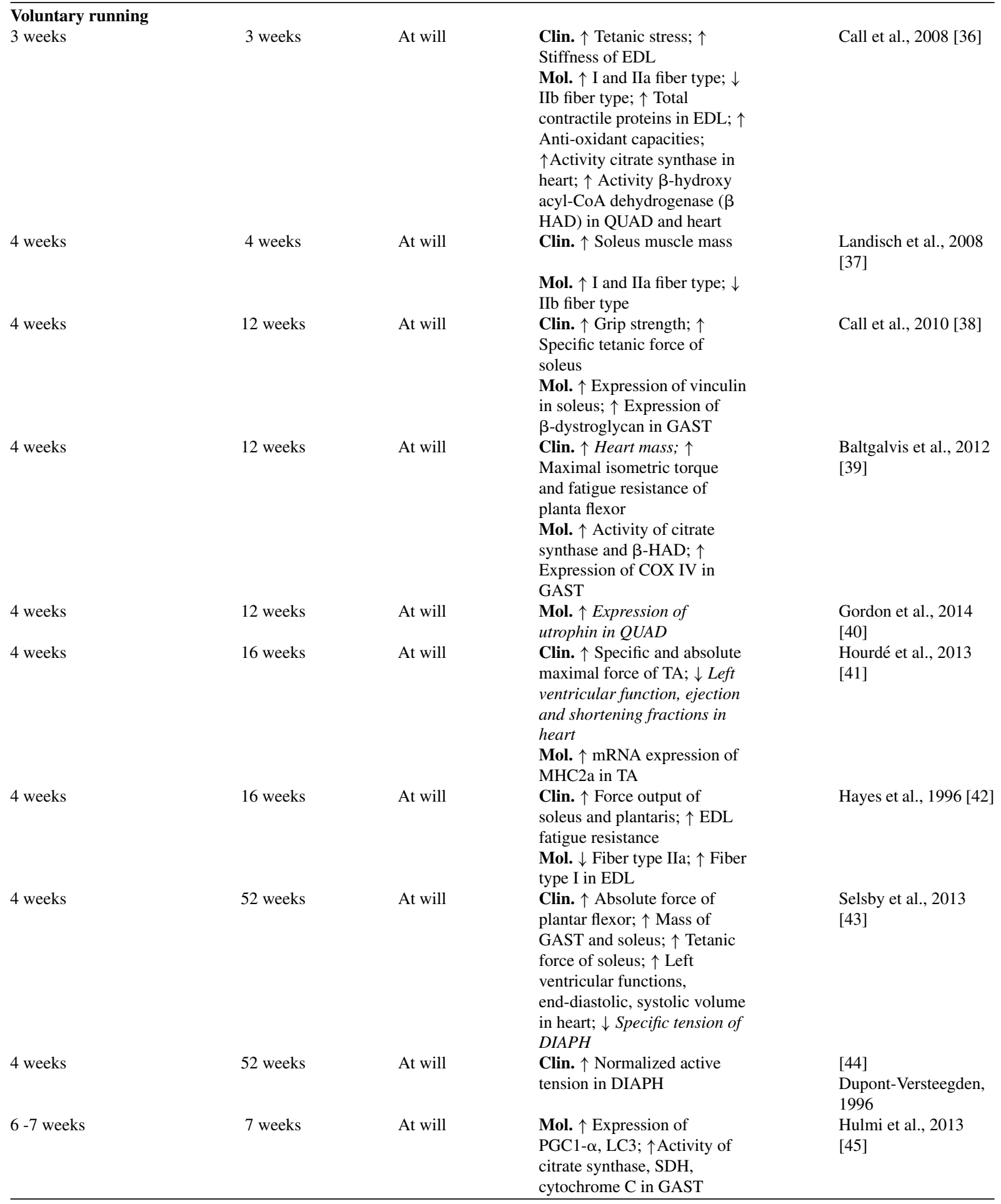




\begin{tabular}{|c|c|c|c|c|}
\hline & & $\begin{array}{r}\text { Tab } \\
\text { (cont }\end{array}$ & & \\
\hline 7 weeks & 4 weeks & At will & $\begin{array}{l}\text { Clin. } \uparrow \text { Dilatation of } \\
\text { ventricles; } \downarrow \text { Size lateral } \\
\text { ventricular walls; } \uparrow \text { Sign of } \\
\text { dystrophin-related } \\
\text { cardiomyopathy and cardiac } \\
\text { fibrosis in heart }\end{array}$ & $\begin{array}{l}\text { Costas et al., } 2010 \\
{[46]}\end{array}$ \\
\hline 8 weeks & 4 weeks & At will & $\begin{array}{l}\text { Clin. } \downarrow \text { Interstitium space; } \uparrow \\
\text { Cross sectional area in triceps } \\
\text { bracialis } \\
\text { Mol. } \uparrow \text { Ubiquitinated } \\
\text { proteins; } \uparrow \text { p-AMPK } \alpha \text { and } \\
\text { p-ACC/ACC ratios in triceps } \\
\text { bracialis }\end{array}$ & $\begin{array}{l}\text { Bueno Júnior et al., } \\
2012 \text { [47] }\end{array}$ \\
\hline 10 weeks & 2 weeks & At will & Mol. $\uparrow$ Necrosis in $Q U A$ & Hunt et al., 2011 [48] \\
\hline $10-12$ weeks & 1 weeks & At will & $\begin{array}{l}\text { Mol. } \uparrow \text { Necrosis in } Q U A \text { and } \\
\text { GAST; Insuffisant resting } \\
\text { increases damages }\end{array}$ & $\begin{array}{l}\text { Smythe et al., } 2011 \\
\text { [49] }\end{array}$ \\
\hline \multirow[t]{2}{*}{12 weeks } & 4 weeks & At will & Clin. $\uparrow$ Kyphosis & $\begin{array}{l}\text { Brereton et al., } 2012 \\
{[50]}\end{array}$ \\
\hline & & & $\begin{array}{l}\text { Mol. } \uparrow \text { Fibrosis in erector } \\
\text { spinae }\end{array}$ & \\
\hline 24 weeks & 12 weeks & At will & $\begin{array}{l}\text { Clin. } \uparrow \text { Cross sectional area } \\
\text { of soleus }\end{array}$ & $\begin{array}{l}\text { Mangner et al., } 2012 \\
{[51]}\end{array}$ \\
\hline 28 weeks & 4 weeks & At will & $\begin{array}{l}\text { Clin. } \uparrow \text { Absolute maximal } \\
\text { force of female } m d x \text { mice; No } \\
\text { sign of cardiomyopathy }\end{array}$ & Ferry et al., 2015 [52] \\
\hline Age & Period & Protocol $^{\mathrm{a}}$ & Effects & Reference \\
\hline \multicolumn{5}{|l|}{ Treadmill running } \\
\hline 4 weeks & $4-8$ weeks & $30 \mathrm{~min}, \mathbf{1 2} \mathbf{m} / \mathbf{m i n}$ & $\begin{array}{l}\text { Clin. } \downarrow \text { Forelimb strength; } \uparrow \\
\text { Degenerative area in GAS }\end{array}$ & $\begin{array}{l}\text { De Luca et al., } 2005 \\
{[53]}\end{array}$ \\
\hline \multirow[t]{2}{*}{4 weeks } & $4-8$ weeks & $30 \mathrm{~min}, \mathbf{1 2} \mathrm{m} / \mathrm{min}$ & Clin. $\downarrow$ Forelimb strength & $\begin{array}{l}\text { De Luca et al., } 2003 \\
{[54]}\end{array}$ \\
\hline & & & $\begin{array}{l}\text { Mol. } \downarrow \mathrm{Cl}^{-} \text {conductance of } \\
\text { DIA and EDL; } \\
\downarrow \text { voltage threshold for } \\
\text { contraction of EDL; } \\
\uparrow \text { necrotic fibers in TA }\end{array}$ & \\
\hline 4 weeks & $4-8$ weeks & $30 \mathrm{~min}, \mathbf{1 2} \mathbf{m} / \mathbf{m i n}$ & $\begin{array}{l}\text { Clin. } \downarrow \text { Strength of EDL } \\
\text { Mol. } \downarrow \mathrm{Cl}^{-} \text {conductance }\end{array}$ & Burdi et al., 2006 [55] \\
\hline 4 weeks & $4-8$ weeks & $30 \mathrm{~min}, \mathbf{1 2} \mathbf{m} / \mathbf{m i n}$ & Clin. $\uparrow$ Plasma ROS & Burdi et al., 2009 [56] \\
\hline 4 weeks & $4-8$ weeks & $30 \mathrm{~min}, \mathbf{1 2} \mathrm{m} / \mathbf{m i n}$ & $\begin{array}{l}\text { Mol. } \uparrow \text { Resting cytoplasmic } \\
{\left[\mathrm{Ca}^{2+}\right] ; \text {; Sarcolemmal }} \\
\text { permeability in EDL }\end{array}$ & $\begin{array}{l}\text { Fraysse et al., } 2004 \\
\text { [57] }\end{array}$ \\
\hline 4 weeks & 6 weeks & $30 \mathrm{~min}, \mathbf{9 m} / \mathbf{m i n}$ & $\begin{array}{l}\text { Mol. } \downarrow \text { Mitochondrial oxygen } \\
\text { consumption; } \uparrow \text { Lipid } \\
\text { peroxydation; } \uparrow \text { Lipofusin } \\
\text { deposition; } \downarrow \text { Quantity of } \\
\text { vitamin } E ; \uparrow \text { Activity } \\
\text { glutathione peroxidase in } \\
\text { QUA and GAS }\end{array}$ & Faist et al., 2001 [58] \\
\hline 4 weeks & 8 weeks & $30 \mathrm{~min}, \mathbf{9 m} / \mathbf{m i n}$ & $\begin{array}{l}\text { Mol. } \downarrow \text { Malondialdehyde } \\
\text { level; } \downarrow \text { Total protein } \\
\text { carbonylation in GAS }\end{array}$ & $\begin{array}{l}\text { Kaczor et al., } 2007 \\
{[59]}\end{array}$ \\
\hline 4 weeks & 8 weeks & $30 \mathrm{~min}, \mathbf{9 m} / \mathbf{m i n}$ & Clin. $\downarrow$ Creatine kinase level & Hall et 2007 [60] \\
\hline 4 weeks & 12 weeks & $30 \mathrm{~min}, \mathbf{1 2 m} / \mathbf{m i n}$ & Mol. $\uparrow$ Fibrosis in QUAD & $\begin{array}{l}\text { van Putten et al., } 2012 \\
\text { [61] }\end{array}$ \\
\hline \multirow[t]{2}{*}{4 weeks } & 12 weeks & $30 \mathrm{~min}, \mathbf{1 2} \mathrm{m} / \mathbf{m i n}$ & Clin. $\downarrow$ Forelimb strength & Camerino et al., 2014 \\
\hline & & & $\begin{array}{l}\text { Mol. } \downarrow \text { mRNA of PGC1- } \alpha \text {, } \\
\text { Sirt1, PPAR } \gamma, \text { Bnip } 3 \text {, } \\
\text { HDAC5, SERCA2, FST, } \\
\text { MYOG in GAS }\end{array}$ & \\
\hline
\end{tabular}




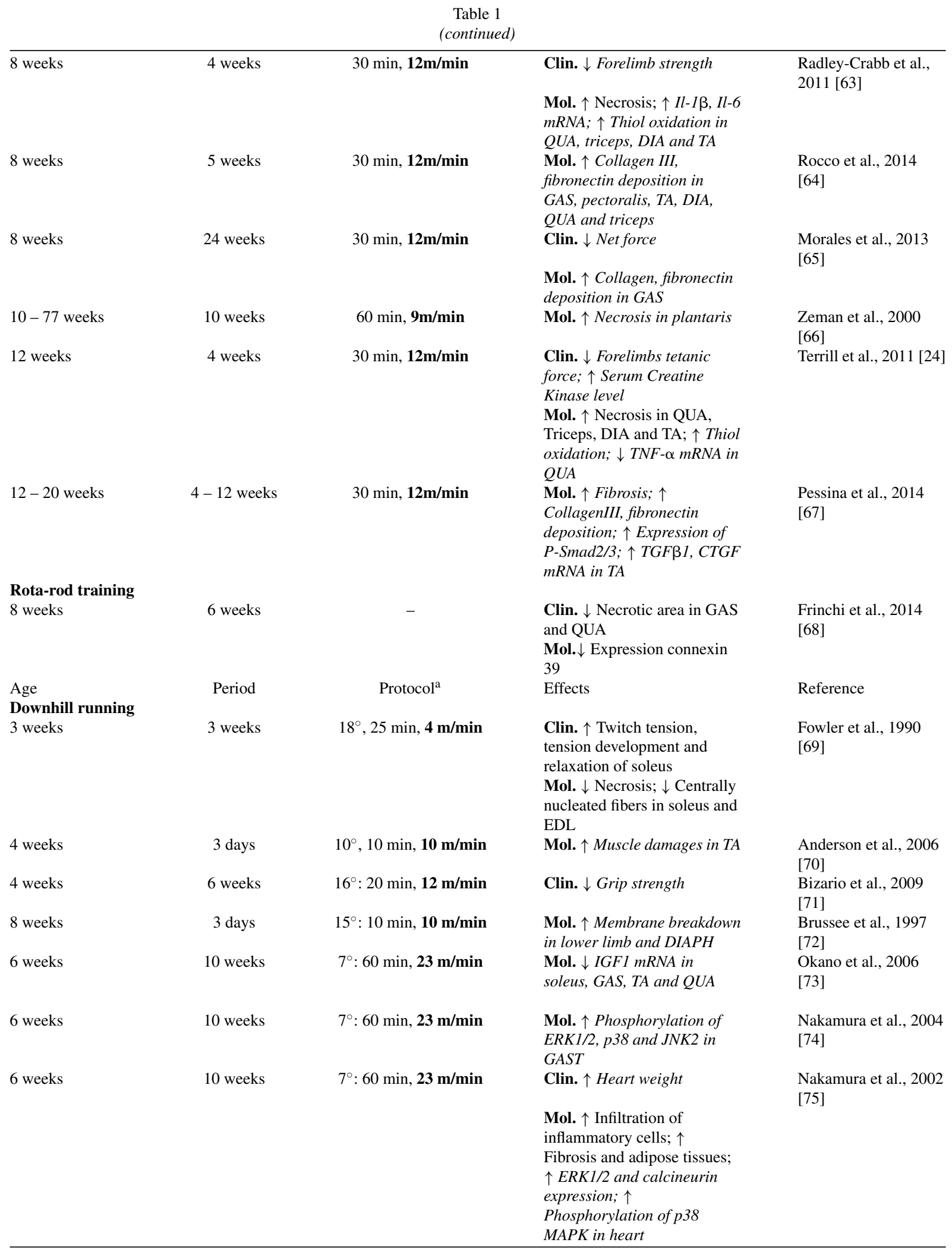




\begin{tabular}{|c|c|c|c|c|}
\hline & & & & \\
\hline 10 weeks & 2 weeks & $15^{\circ}: 10 \mathrm{~min}, \mathbf{1 5} \mathrm{m} / \mathrm{min}$ & Clin. $\downarrow$ Strength of EDL & $\begin{array}{l}\text { Kobayashi et al., } 2011 \\
\text { [76] }\end{array}$ \\
\hline & & & $\begin{array}{l}\text { Mol. } \uparrow \text { Exercise-induced } \\
\text { myoglobinuria; } \uparrow \text { Oedema } \\
\text { and inflammation in GAS and } \\
Q U A\end{array}$ & \\
\hline 24 weeks & 7 weeks & $15^{\circ}: 60 \mathrm{~min}, \mathbf{1 7} \mathrm{m} / \mathrm{min}$ & Clin. $\downarrow$ Grip strength & $\begin{array}{l}\text { Taniguti et al., } 2011 \\
\text { [77] }\end{array}$ \\
\hline & & & $\begin{array}{l}\text { Mol. } \uparrow \text { Fibrosis in DIA and } \\
\text { biceps brachii; } \uparrow \text { Expression } \\
\text { of TGF } \beta 1 \text { in biceps brachii } \\
\text { and heart }\end{array}$ & \\
\hline
\end{tabular}

Normal words signal a positive effect of exercise. Underscored words signal a neutral effect of exercise. Italic words signal a negative effect

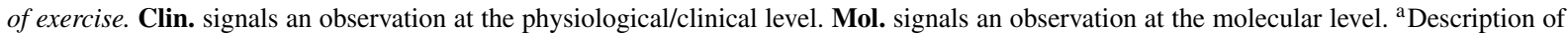
experimental protocol with duration of exercise, speed or slope value if appropriate. Abbreviations: DIA Diaphragm; EDL Extensor Digitorum Longus; FGF Fibroblast Grown Factor; GAST Gastrocnemius; QUA Quadriceps; ROS Reactive Oxygen Species; TA Tibialis Anterior.

quently, studies should investigate different muscles simultaneously. However, most studies focused on the effects of exercise on hindlimbs; others investigated the diaphragm $[43,44,77]$ or the heart $[38,39,41$, $43,46,75]$. The hindlimbs and the diaphragm of 4week-old $m d x$ mice tolerate the effects of voluntary running well (Table 1B), whereas necrosis and fibrosis occur after 10 weeks of age. Conversely, cardiac complications appear after voluntary running in 4week-old $m d x$ mice, with increased cardiac mass [39] and impaired function [41, 43]. Effects of swimming on cardiac function have only been investigated preliminarily. Our own results have shown that 30 minutes daily swimming from 8 to 16 weeks of age had no influence on cardiac weight (Hyzewicz, unpublished data), but further investigations are necessary.

The studies cited above were performed using male $m d x$ mice. Studies using female $m d x$ mice at 24-28 weeks of age did not reveal signs of cardiomyopathy after voluntary running [52]. Interestingly, female $m d x$ mice were more susceptible than males to develop cardiac problems [79]. Further studies must be conducted to determine whether voluntary running can protect female hearts from complications.

\section{Investigations of physical exercise on mdx mouse muscle}

Acute exercise (Table 1A) leads to membrane leakiness, even under mild conditions such as swimming using 4-week-old mice [21]. Voluntary running in 10week-old $m d x$ mice also causes apoptotic events in the tibialis anterior muscle [23]. Necrosis, thiol oxidation and increased expression of interleukin (IL)-6 mRNA have been reported in quadriceps muscle of 12-week-old mice after 30 minutes of treadmill run- ning at $12 \mathrm{~m} / \mathrm{min}$ [24]. These results show that even single bouts of exercise can cause muscle damage in $m d x$ mice.

In wild type mice, adaptation to chronic exercise leads to large changes in signal transduction mechanisms [8], including subfamilies of the mitogenactivated protein kinase (MAPK) signalling pathways, namely: extracellular signal-regulated kinase (ERK) 1/2, c-Jun N-terminal kinase (JNK), and p38 MAPK [80]. These signalling pathways are activated by reactive oxygen species and lead to activation of genes involved in mitochondrial adaptation, such as PGC1- $\alpha$, and muscle differentiation [81]. In $m d x$ skeletal muscle, production of such species is abnormally elevated, owing to either mitochondrial $\mathrm{Ca}^{2+}$ overload [82] or over-activation of membrane-bound NADPH oxidase 2 [83]. Chronic exercise studies using 6-8-week-old $m d x$ mice that performed 10 weeks of downhill running on a $7^{\circ}$ slope at $23 \mathrm{~m} / \mathrm{min}$ for 1 hour showed that proteins downstream of MAPK were over-phosphorylated $[74,75]$. This protocol also resulted in infiltration of immune cells, fibrosis, and deposits of adipose tissues in skeletal muscle and heart. Chronic treadmill running at $12 \mathrm{~m} / \mathrm{min}$ for $30 \mathrm{~min}$ caused downregulation of Sirt1, PGC1- $\alpha$, PPAR $\gamma$ and myogenin in 4-week-old animals [62].

In contrast, low intensity training is beneficial. Expression of mitochondrial $[39,45]$ and muscle differentiation [41] genes was increased after voluntary wheel running in 4-8-week-old animals (Table 1B). Low intensity swimming and running in young $m d x$ mice also stimulated a switch from fast glycolytic muscle (type IIb) to oxidative (type IIa) and slow (type I) muscle [34, 37]. Despite this switch, protein expression in slow and fast skeletal muscle increased after low intensity swimming in 4-week-old mice [30]. 
Comparison of wild type and $m d x$ muscle following low intensity swimming also pointed to higher protein expression levels in $m d x$ fibres [30]. This observation suggests that dystrophic muscles could benefit from smaller quantities of training than wild type muscles. The fact that hypoxia is more severe in muscles of $m d x$ mice than in wild types could explain this phenomenon, since stimulation of HIF-1 initiates adaptation to training via the MAPK signalling pathway [34].

\section{Exercise as a means to worsen the dystrophic phenotype}

The mild disease phenotype in $m d x$ mice causes a bias when assessing effectiveness of potential drugs for DMD therapy. To worsen the $m d x$ phenotype, researchers increase the mechanical stress using voluntary wheel running [50], treadmill [24, 53-56, 65, 66] or downhill running [70, 71, 73, 77] (Table 1). We compared these protocols to determine which types of exercise are likely to make $m d x$ muscles become more like those in patients with DMD.

Voluntary running in 10-12-week-old animals caused a suitable worsening of the $m d x$ phenotype, showing fibrosis, kyphosis [50] and necrosis of quadriceps muscle [48]. Similar results were obtained with treadmill running in 4 -week-old mice for 4 weeks at $12 \mathrm{~m} / \mathrm{min}$, leading to fibrosis [61], gastrocnemius degeneration [59], decreased forelimb strength [24, $55]$ and elevated levels of reactive oxygen species in plasma [56]. Twelve weeks of training also caused downregulation of Sirt1, PGC1- $\alpha$ and PPAR $\gamma$ mRNA expression [62]. However, the acute damaging effects of exercise tended to disappear 96 hours after training, as shown by decreased levels of mRNA coding for pro-inflammatory IL-1 $\beta$ and IL-6 [63].

Downhill running was reported to result in increased muscle damage and decreased grip strength [70, 71], but no information about fibrosis or inflammation was available in these reports. The most complete studies on downhill running showed evidence of fibrosis, adipose tissue and infiltration of immune cells in the hearts of 18 -week-old mice after 10 weeks of running on a $7^{\circ}$ slope at $23 \mathrm{~m} / \mathrm{min}$ [75], or decreased muscle strength, increased myoglobinuria and inflammation in 12-week-old mice after 2 weeks of training on a $15^{\circ}$ slope at $15 \mathrm{~m} / \mathrm{min}$ [76].

Based on these observations, we conclude that to worsen the phenotype of $m d x$ mice, a minimum of 4 weeks of voluntary exercise from 10 weeks of age, or at least 4 weeks of treadmill running at $12 \mathrm{~m} / \mathrm{min}$ from 4 weeks of age, is required. Furthermore, in order to avoid the bias due to acute exercise effects, the ability of drugs to prevent exercise-induced damage should be ideally measured with a proper lag time (around 2-3 days) after last exercise bout [54].

\section{TREAT-NMD protocols for exercise in mdx mice}

TREAT-NMD is a network for research on neuromuscular diseases that proposes standard operating procedures (SOPs) for experiments with the aim of improving comparability between studies [84]. Two exercise protocols were proposed for $m d x$ mice: one to worsen the phenotype [85] and the other to assess the progression of the dystrophic state [86]. Both are based on previous publications on wheel $[21,32,35$, $36]$ or treadmill $[53,54,56]$ running.

The first protocol advised that 3-4-week-old mice perform voluntary wheel running 1-7 days/week, or treadmill exercise at $12 \mathrm{~m} / \mathrm{min}$ for 30 minutes twice per week. Based on our review (section 2.3.3), treadmill exercise in mice aged 3-4 weeks is suitable for worsening the $m d x$ phenotype, but voluntary wheel running requires the mice to be at least 10 weeks old; in younger mice, the benefits of exercise counteract the aggravation of the dystrophic phenotype [36-38].

The second protocol also suggested voluntary wheel running 1-7 days/week, or treadmill exercise at 9 or $12 \mathrm{~m} / \mathrm{min}$ for 30 minutes twice a week, in young mice. Authors recommended avoiding downhill running since $m d x$ mice barely tolerate this exercise. They also pointed out that all mice should perform the same amount of exercise, especially during voluntary wheel running. We agree with these recommendations.

SOPs are an important tool for harmonizing experiments between laboratories. We suggest adding protocols for swimming training based on previous publications [21, 30-35].

\section{EXPERIMENTAL PROCEDURES FOR EXERCISE IN PATIENTS WITH DMD}

\section{Literature search for exercise studies in patients with DMD}

We performed a literature search in PubMed, using the keywords "DMD" and "exercise", which was completed on 25 May 2015. A total of 167 articles were examined. Twenty-five of them reported effects of exercise in patients with DMD and described the protocol or results; these formed the basis of this part of the review. They were classified according to the type of muscle performing the exercise and are listed in Table 2. 
Table 2

Effects of physical exercise on Duchenne Muscular Dystrophy patients

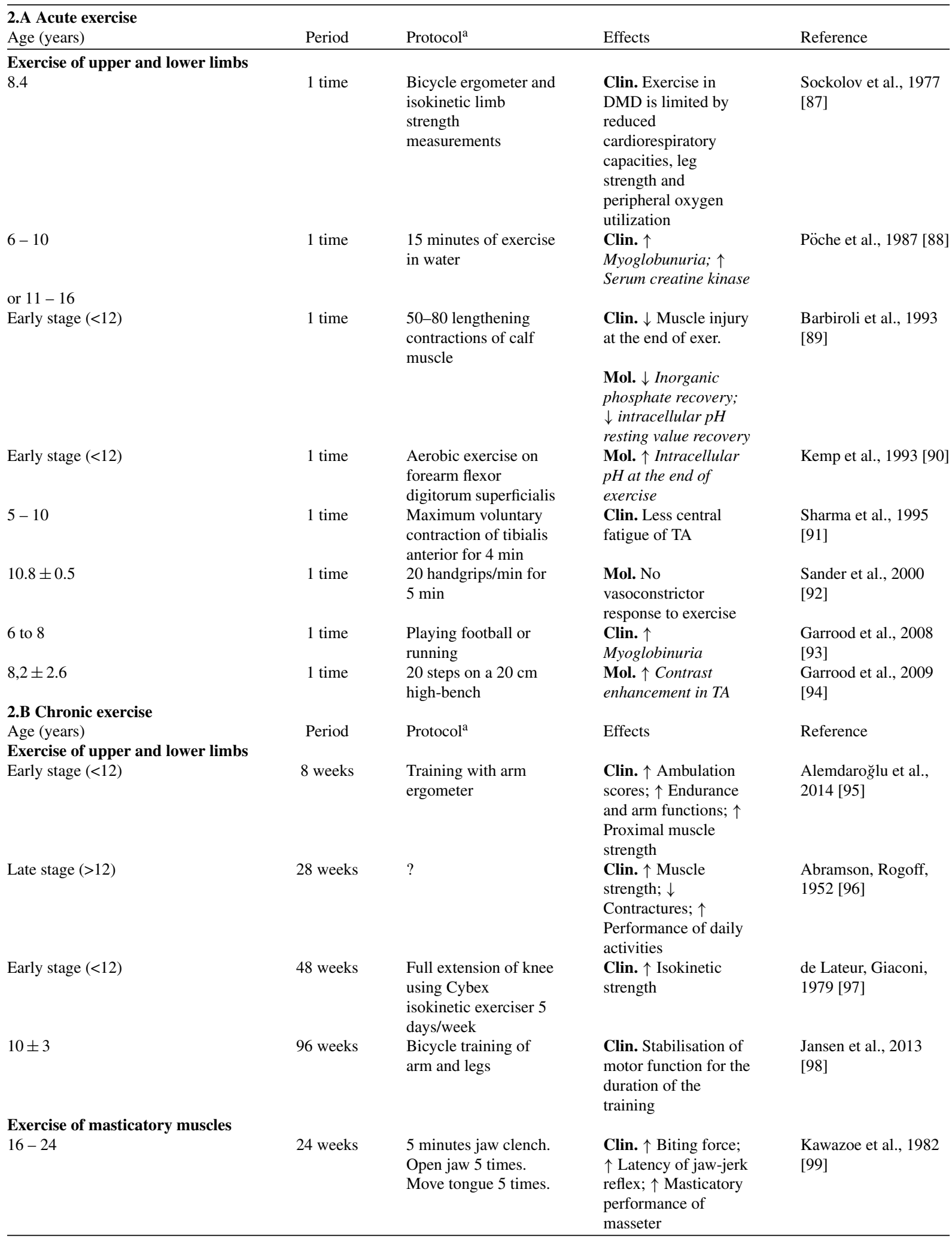


Table 2

(continued)

\begin{tabular}{|c|c|c|c|c|}
\hline 20 & 24 weeks & $\begin{array}{l}\text { Massage of masseter } \\
10 \text { min and jaw } \\
\text { training } 5 \text { min per day }\end{array}$ & $\begin{array}{l}\text { Clin. } \uparrow \text { Greatest } \\
\text { occlusal force; } \uparrow \\
\text { Satisfaction to eat }\end{array}$ & $\begin{array}{l}\text { Nozaki et al., } 2010 \\
{[100]}\end{array}$ \\
\hline Age & Period & Protocol $^{\mathrm{a}}$ & Effects & Reference \\
\hline \multicolumn{5}{|l|}{ Exercise of respiratory muscles } \\
\hline$\approx 11.4$ & 2.5 weeks & $\begin{array}{l}\text { Triflow II } \\
\text { inspirometer, } 20 \\
\text { inspirations/day }\end{array}$ & $\begin{array}{l}\text { Clin. No benefit of } \\
\text { exercise }\end{array}$ & $\begin{array}{l}\text { Rodillo et al., } 1989 \\
\text { [101] }\end{array}$ \\
\hline \multirow[t]{2}{*}{ Late stage $(>12)$} & 5 weeks & $\begin{array}{l}\text { Video game ajusted to } \\
\text { respiratory efforts, } 10 \\
\mathrm{~min} / \text { day }\end{array}$ & $\begin{array}{l}\text { Clin. } \uparrow \text { Maximum } \\
\text { voluntary respiration; }\end{array}$ & $\begin{array}{l}\text { Vilozni et al., } 1994 \\
\text { [102] }\end{array}$ \\
\hline & & & $\begin{array}{l}\uparrow \text { Maximal achieved } \\
\text { respiration } \\
\uparrow \text { Duration of } \\
\text { progressive isocapnic } \\
\text { hyperventilation } \\
\text { manœuvre }\end{array}$ & \\
\hline $14.4 \pm 5$ & 6 weeks & $\begin{array}{l}\text { Inspiratory resistance } \\
15 \text { min, twice/day }\end{array}$ & $\begin{array}{l}\text { Clin. } \uparrow \text { Maximum } \\
\text { resistance and } \\
\text { maximum duration of } \\
\text { ventilation }\end{array}$ & $\begin{array}{l}\text { DiMarco et al., } 1985 \\
\text { [103] }\end{array}$ \\
\hline 18 & 6.5 weeks & $\begin{array}{l}\text { Inspiratory muscle } \\
\text { training } 5 \text { to } 30 \\
\text { min/day }\end{array}$ & $\begin{array}{l}\text { Clin. } \uparrow \text { Vital capacity; } \\
\uparrow \text { Maximal inspiratory } \\
\text { airway pressure }\end{array}$ & $\begin{array}{l}\text { Aldrich, Uhrlass, } \\
1987 \text { [104] }\end{array}$ \\
\hline $14.7 \pm 4.5$ & 6 weeks & $\begin{array}{l}\text { Breathing through a } \\
\text { valve } 10 \mathrm{~min}, \\
\text { twice/day }\end{array}$ & $\begin{array}{l}\text { Clin. } \uparrow \text { Endurance of } \\
\text { respiratory muscles }\end{array}$ & $\begin{array}{l}\text { Topin et al., } 2002 \\
{[105]}\end{array}$ \\
\hline $14.5 \pm 3.8$ & 24 weeks & $\begin{array}{l}\text { Breathing through a } \\
\text { valve } 10 \mathrm{~min} \text {, } \\
\text { twice/day }\end{array}$ & $\begin{array}{l}\text { Clin. } \uparrow \text { Maximal sniff } \\
\text { assessed esophageal } \\
\text { and } \\
\text { transdiaphragmatic } \\
\text { pressure; } \uparrow \\
\text { Inspiratory muscle } \\
\text { endurance }\end{array}$ & $\begin{array}{l}\text { Wanke et al., } 1994 \\
\text { [106] }\end{array}$ \\
\hline 12 & 24 weeks & $\begin{array}{l}\text { Resistive inspiration } \\
\text { and expiratory loads }\end{array}$ & $\begin{array}{l}\text { Clin. } \uparrow \text { Maximal } \\
\text { static inspiratory and } \\
\text { expiratory pressures; } \\
\downarrow \text { Decreased } \\
\text { respiratory load } \\
\text { perception }\end{array}$ & $\begin{array}{l}\text { Gozal, Thiriet, } 1999 \\
\text { [107] }\end{array}$ \\
\hline $8-29$ & 36 weeks & $\begin{array}{l}\text { Force training then } \\
\text { endurance training } 10 \\
\text { times, twice/day }\end{array}$ & $\begin{array}{l}\text { Clin. } \uparrow \text { Maximal } \\
\text { inspiratory mouth } \\
\text { pressure; } \uparrow \\
12 \text { s-maximum } \\
\text { voluntary ventilation }\end{array}$ & $\begin{array}{l}\text { Winkler et al., } 2000 \\
\text { [108] }\end{array}$ \\
\hline $9.5 \pm 2.3$ & 40 weeks & $\begin{array}{l}\text { Yoga training: [fast } \\
\text { pelvic contractions], } \\
\text { [forced apnea after } \\
\text { expiration] and } \\
\text { [maximal contraction } \\
\text { followed by apnea] }\end{array}$ & $\begin{array}{l}\text { Clin. } \uparrow \text { Increased of } \\
\text { force vital capacity; } \uparrow \\
\text { Forced expiratory } \\
\text { volume in } 1 \text { second }\end{array}$ & $\begin{array}{l}\text { Rodrigues et al., } 2014 \\
\text { [109] }\end{array}$ \\
\hline $12.5 \pm 2.3$ & 96 weeks (2 years) & $\begin{array}{l}\text { Breathing through a } \\
\text { valve } 10 \mathrm{~min} \text {, } \\
\text { twice/day }\end{array}$ & $\begin{array}{l}\text { Clin. } \uparrow \text { Maximal } \\
\text { inspiratory mouth } \\
\text { pressure; } \uparrow \\
12 \text { s-maximum } \\
\text { voluntary ventilation }\end{array}$ & $\begin{array}{l}\text { Koessler et al., } 2001 \\
\text { [110] }\end{array}$ \\
\hline $\begin{array}{l}16.5 \pm 4 \\
19.9 \pm 5\end{array}$ & & & & \\
\hline
\end{tabular}

Normal words signal a positive effect of exercise. Underscored words signal a neutral effect of exercise. Italic words signal a negative effect of exercise. Clin. signals an observation at the physiological/clinical level. Mol. signals an observation at the molecular level. ${ }^{\mathrm{a}}$ Description of experimental protocol with duration of exercise, speed and other parameters. Abbreviations: TA Tibialis Anterior. 
The purpose of exercise studies in DMD patients

Physical training was mainly used to assess therapeutic methods for improving dystrophic muscle capacity in wheelchair-dependent patients with DMD, measuring the effects of exercise on respiratory or masticatory muscles. Several studies investigated the effects of acute exercise (Table 2A). Studies assessing therapeutic exercises at early stages of the disease (before 10 years of age) were rare, and mainly used chronic training of upper and lower limbs (Table 2B).

\section{Therapeutic training in patients with DMD before wheelchair dependence}

Only three studies focused on improving ambulation in young patients by arm and leg training $[95,97$, 98] (Table 1B). Interestingly, documentation for parents of DMD patients recommends physical exercise during the early stages of the disease $[10,111]$ based on observations in $m d x$ mice [111]. Moderate exercise is recommended, without pushing the child, and stopping before the threshold of exhaustion, switching to cycling or swimming when difficulties become apparent.

Bicycle [98] or ergometer [95, 97] training in young DMD patients confirmed the benefit of long-term physical exercise from early stages of the disease. However, two studies showed that running or step exercise damaged the tibialis anterior muscle and caused myoglobinuria immediately after training in patients aged 6-10 years $[93,94]$. Theoretically, damage induced by short-term exercise does not prevent long-term improvement in muscle status. But the benefits of training have been demonstrated on bicycle and ergometer, whereas studies reporting short-term negative effects have involved running or step exercises without equipment. The long-term benefits of non-assisted leg training remain to be demonstrated.

Swimming is often recommended for DMD patients [98, 112], but only one study has investigated its effects, and found that myoglobin and creatine kinase levels were elevated after training [88].

\section{Therapeutic training in patients with DMD after wheelchair dependence}

The first demonstration that muscle training could improve the daily life of late-stage DMD patients was in 1952 [98], but used no control, and was therefore hard to interpret [113]. Subsequent studies demonstrated that appropriate training could improve the capacity of masticatory and respiratory muscles in wheelchair-dependent patients with DMD.
For masticatory muscles, two studies showed that jaw and tongue training for 24 weeks, accompanied by massage of the masseter muscle, could improve jaw performance and ease of eating [99, 100] (Table 2B).

For respiratory muscles, two approaches were followed: non-assisted or assisted training. Non-assisted training involved resistive inspiratory muscle training [103, 104] or yoga [109]. Assisted training involved the use of special apparatus [101, 108], video games [102], breathing through a valve [105, 106, 110] or resistance to a load [107] (Table 2B).

All studies except one [101] reported an improvement in patients' respiratory capacity. Non-assisted training improved maximal resistance, duration of ventilation [103], inspiratory airway pressure [104], forced expiratory volume in $1 \mathrm{~s}$ [109], and vital capacity [104, 109]. Assisted training improved maximal voluntary respiration, maximal achieved respiration [102], maximal sniff assessed oesophageal and transdiaphragmatic pressure [105], static inspiratory/expiratory pressures [107] and inspiratory mouth pressure, as well as $12 \mathrm{~s}$ maximal voluntary ventilation [108, 110], duration of progressive isocapnic hyperventilation manoeuvre [102] and respiratory muscle endurance [105, 106].

Non-assisted and assisted respiratory training data are not comparable because different parameters were measured. Only one study compared the effects of nonassisted and load-assisted training and concluded that non-assisted training had no effect [107].

In conclusion, training of respiratory muscles successfully delays the need for mechanical ventilation [104], but there is a lack of studies comparing nonassisted and assisted respiratory training to determine whether training equipment is useful for therapeutic purposes or could be replaced by non-assisted inspiratory training.

\section{Investigating acute exercise in patients with DMD}

An early ergometer study showed that DMD patients have limited adaptation to exercise owing to reduced cardiorespiratory capacity, weaker leg strength and limited use of peripheral oxygen [87] (Table 2A). Arm muscle training studies revealed that the intracellular $\mathrm{pH}$ at the end of the exercise was higher in DMD muscle fibres than in healthy patients and that inorganic phosphate and $\mathrm{pH}$ recovery rates were lower $[89,90]$. These differences were explained in part by the fact that the vasoconstrictor response of dystrophic muscles is not blunted in response to exercise [92]. In contrast, DMD patients feel less fatigue and have less muscle injury at the end of most types of exercise $[89,91]$. 


\section{DIFFERENCES IN RESEARCH APPROACHES BETWEEN MICE AND HUMANS}

Research in animal models is commonly the first step before clinical trials in patients. However, because the $m d x$ mouse was discovered only in 1984 [16], much after the first report in humans in 1868 [114], experiments investigating the effect of physical exercise on dystrophic muscles began in DMD patients 40 years before the first studies in $m d x$ mice. Here, we have reviewed 80 articles and found none reporting results from both the murine model and patients. The consequence is a large number of differences between results of studies in mice and humans.

\section{Research focusing on respiratory function in patients with DMD}

The majority of investigations in patients with DMD aimed to improve respiratory function alone, and recruited mainly wheelchair-dependent patients [101-110]. In comparison, only three studies document results of investigations of respiratory function in exercised $m d x$ mice $[43,44,77]$. However, limb and diaphragm muscles were investigated together in $m d x$ mice, but separately in patients with DMD.

\section{Effect of exercise on cardiac function in patients with DMD}

Since the development of mechanical ventilation, cardiac failure has become the primary cause of death of DMD patients. Experiments in exercised $m d x$ mice demonstrated a vulnerability of cardiac muscle with running, even with low intensity training [39, 41, 43]. However, no study in patients with DMD has ever investigated the impact of exercise on the heart. The limits of exercise for DMD patients should be adjusted by taking into account the limits of the cardiac muscle, especially because experiments in mice have shown that voluntary training can also damage the heart. This aspect is important because it suggests that children with DMD might exercise over their limit, without considering the damage occurring in their heart.

\section{Swimming is recommended for patients, but without evidences}

Swimming exercise appears intuitively to be beneficial for DMD patients, because water supports a large part of the patient's weight and thus reduces mechan- ical stress. However, benefits of water training have never been assessed in patients and scarcely investigated in mice. Vulnerability of the $m d x$ heart has been observed with running [39, 41, 43], but results from preliminary studies of swimming (Hyzewicz, unpublished data) suggest that this exercise might spare the cardiac muscle. If further studies confirm the harmlessness of swimming, then it should become a research priority in patients with DMD.

\section{CONCLUSIONS}

We have reviewed here the present state of research into the effects of physical exercise on dystrophic muscles, and suggested further investigations to establish evidence-based recommendations regarding optimal training modes. The main conclusions we have drawn are summarized in Fig. 2 and outlined below.

Studies in $m d x$ mice have demonstrated that voluntary running exercise in 4-week-old animals improves hindlimb and diaphragm capacity but is harmful for the heart. The effects of swimming on cardiac tissue have not yet been studied. Forced treadmill running of at least 4-week-old mice at $12 \mathrm{~m} / \mathrm{min}$ for 4 weeks renders the $m d x$ phenotype closer to that of DMD patients.

Studies in human have shown that respiratory and masticatory muscle training successfully improves functional capacity in patients aged 12 years or older. However, further comparisons between machineassisted respiratory training and non-assisted training are necessary. Bicycle training can also delay the impairment of motor function in young patients, although the effects of exercise on cardiac function have not yet been investigated. There is also a lack of studies investigating the effect of running and swimming in DMD.

In order to fill these knowledge gaps, we suggest the following approaches for future research regarding the effects of physical exercise on $m d x$ mice and DMD patients:

1. As DMD causes degeneration of respiratory, cardiac and limb muscles, future studies should assess the effects of exercise on these three types of muscle simultaneously.

2. Running has a negative effect on the heart in $m d x$ mice. It is crucial to determine whether a similar effect occurs in the hearts of patients with DMD after running.

3. Effects of exercise on young DMD patients (4-12 years old) should be investigated. 
Effects of physical exercise on dystrophin-deficient muscles

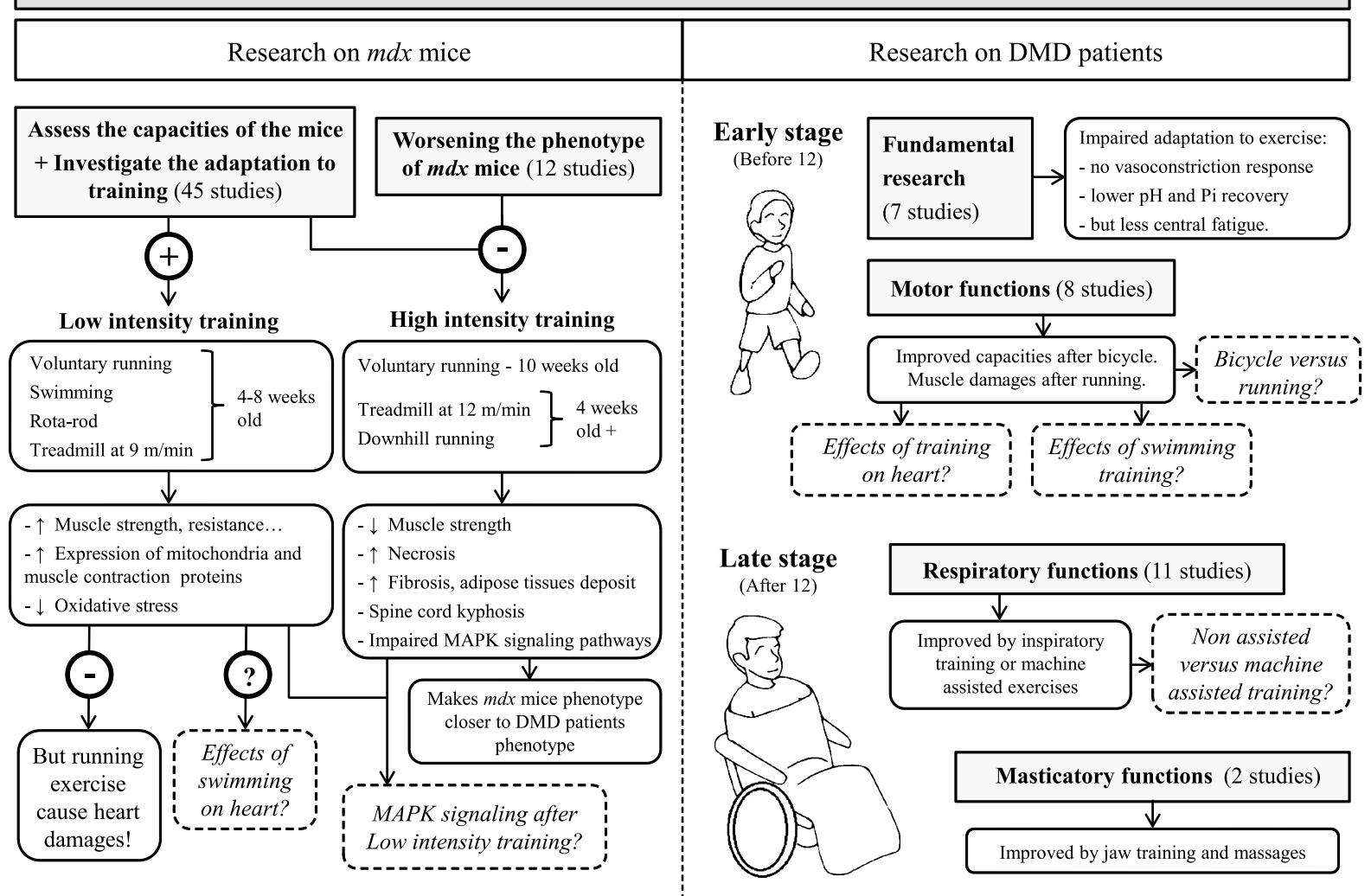

Fig. 2. Schematic summarizing the effects of physical exercise on dystrophin-deficient muscles. Results from studies investigating the effects of physical exercise on muscles in $m d x$ mice (left panel) and DMD patients (right panel). Dotted lines represent open questions.

4. Even though swimming is recommended, its cardiac consequences have not been studied in $m d x$ mice or patients. This should be performed using appropriate technology, such as MRI and biomarker measurement.

5. Studies should compare non-assisted respiratory training with machine-assisted training.

\section{ACKNOWLEDGMENTS}

We thank the Department of Molecular Therapy, National Center of Neurology and Psychiatry, for support and useful discussions. We are also grateful to the Library of the National Center of Neurology and Psychiatry for help in gathering bibliographic material. This work was supported by an Intramural Research Grant (25-5) for Neurological and Psychiatric Disorders of the National Center of Neurology and Psychiatry.

\section{CONFLICT OF INTEREST}

The authors have no conflict of interest to report.

\section{REFERENCES}

[1] Bushby K, Finkel R, Birnkrant DJ, Case LE, Clemens PR, Cripe L, et al. DMD Care Considerations Working Group. Diagnosis and management of Duchenne muscular dystrophy, part 2: Implementation of multidisciplinary care. Lancet Neurol. 2010;9(2):177-89. doi: 10.1016/S14744422(09)70272-8.

[2] Matsumura T, Saito T, Fujimura H, Shinno S, Sakoda S. A longitudinal cause-of-death analysis of patients with Duchenne muscular dystrophy. Rinsho Shinkeigaku. 2011;51(10):743-50

[3] Biggar WD, Harris VA, Eliasoph L, Alman B. Long-term benefits of deflazacort treatment for boys with Duchenne muscular dystrophy in their second decade. Neuromuscul Disord. 2006;16:249-55.

[4] Kinali M, Messina S, Mercuri E, Lehovsky J, Edge G, Manzur AY, et al. Management of scoliosis in Duchenne muscular dystrophy: A large 10-year retrospective study. Dev Med Child Neurol. 2006;48(6):513-8. 
[5] Hull J, Aniapravan R, Chan E, et al. British Thoracic Society guideline for respiratory management of children with neuromuscular weakness. Thorax. 2012;67(suppl 1):1-40.

[6] Bushby K, Finkel R, Wong B, Barohn R, Campbell C, Comi GP, et al. Ataluren treatment of patients with nonsense mutation dystrophinopathy. Muscle Nerve. 2014;50(4):47787.

[7] Ruegg UT. Pharmacological prospects in the treatment of Duchenne muscular dystrophy. Curr Opin Neurol. 2013;26(5):577-84. doi: 10.1097/WCO.0b013e328364fbaf.

[8] Egan B1, Zierath JR. Exercise metabolism and the molecular regulation of skeletal muscle adaptation. Cell Metab. 2013;17(2):162-84. doi: 10.1016/j.cmet.2012.12.012.

[9] Eagle M. Report on the muscular dystrophy campaign workshop: Exercise in neuromuscular diseases Newcastle, January 2002. Neuromuscul Disord. 2002;12(10):975-83.

[10] Annexstad EJ, Lund-Petersen I, Rasmussen M. Duchenne muscular dystrophy. Tidsskr Nor Laegeforen. 2014;134(14):1361-4.

[11] Leung DG, Wagner KR. Therapeutic advances in muscular dystrophy. Ann Neurol. 2013;74(3):404-11.

[12] Markert CD, Ambrosio F, Call JA, Grange RW. Exercise and Duchenne muscular dystrophy: Toward evidence-based exercise prescription. Muscle Nerve. 2011;43(4):464-78.

[13] Barnabei MS, Martindale JM, Townsend D, Metzger JM. Exercise and muscular dystrophy: Implications and analysis of effects on musculoskeletal and cardiovascular systems. Compr Physiol. 2011;1(3):1353-63.

[14] Bushby K, Finkel R, Birnkrant DJ, Case LE, Clemens PR, Cripe L, et al. DMD Care Considerations Working Group. Diagnosis and management of Duchenne muscular dystrophy, part 1: Diagnosis, and pharmacological and psychosocial management. Lancet Neurol. 2010;9(1):77-93.

[15] Abresch RT, Carter GT, Han JJ, McDonald CM. Exercise in neuromuscular diseases. Phys Med Rehabil Clin N Am. 2012;23(3):653-73.

[16] Bulfield G, Siller WG, Wight PA, Moore KJ. X chromosome-linked muscular dystrophy $(\mathrm{mdx})$ in the mouse. Proc Natl Acad Sci U S A. 1984;81(4):1189-92.

[17] Grounds MD. Two-tiered hypotheses for Duchenne muscular dystrophy. Cell Mol Life Sci. 2008;65(11):1621-5.

[18] Partridge TA. The mdx mouse model as a surrogate for Duchenne muscular dystrophy. FEBS J. 2013;280(17):4177-86.

[19] Turk R, Sterrenburg E, de Meijer EJ, van Ommen GJ, den Dunnen JT, 't Hoen PA. Muscle regeneration in dystrophindeficient mdx mice studied by gene expression profiling. BMC Genomics. 2005;6:98.

[20] Abdel-Salam E, Abdel-Meguid I, Korraa SS. Markers of degeneration and regeneration in Duchenne muscular dystrophy. Acta Myol. 2009;28(3):94-100.

[21] Bouchentouf M, Benabdallah BF, Mills P, Tremblay JP. Exercise improves the success of myoblast transplantation in mdx mice. Neuromuscul Disord. 2006;16(8):518-29.

[22] Archer JD, Vargas CC, Anderson JE. Persistent and improved functional gain in $\mathrm{mdx}$ dystrophic mice after treatment with L-arginine and deflazacort. FASEB J. 2006;20(6):738-40.

[23] Podhorska-Okolow M, Sandri M, Zampieri S, Brun B, Rossini K, Carraro U. Apoptosis of myofibres and satellite cells: Exercise-induced damage in skeletal muscle of the mouse. Neuropathol Appl Neurobiol. 1998;24(6):518-31.

[24] Terrill JR, Radley-Crabb HG, Grounds MD, Arthur PG. N-Acetylcysteine treatment of dystrophic mdx mice results in protein thiol modifications and inhibition of exercise induced myofibre necrosis. Neuromuscul Disord. 2012;22(5):427-34.

[25] Quinlan JG, Wong BL, Niemeier RT, McCullough AS, Levin L, Emanuele M. Poloxamer 188 failed to prevent exercise-induced membrane breakdown in mdx skeletal muscle fibers. Neuromuscul Disord. 2006;16(12):855-64.

[26] Whitehead NP, Streamer M, Lusambili LI, Sachs F, Allen DG. Streptomycin reduces stretch-induced membrane permeability in muscles from mdx mice. Neuromuscul Disord. 2006;16(12):845-54

[27] Clarke MS, Khakee R, McNeil PL. Loss of cytoplasmic basic fibroblast growth factor from physiologically wounded myofibers of normal and dystrophic muscle. J Cell Sci. 1993;106(Pt 1):121-33.

[28] Vilquin JT, Brussee V, Asselin I, Kinoshita I, Gingras M, Tremblay JP. Evidence of mdx mouse skeletal muscle fragility in vivo by eccentric running exercise. Muscle Nerve. 1998;21(5):567-76.

[29] Mathur S, Vohra RS, Germain SA, Forbes S, Bryant ND, Vandenborne $\mathrm{K}$, et al. Changes in muscle $\mathrm{T} 2$ and tissue damage after downhill running in mdx mice. Muscle Nerve. 2011;43(6):878-86.

[30] Hyzewicz J, Tanihata J, Kuraoka M, Ito N, Miyagoe-Suzuki Y, Takeda S. Low intensity training of mdx mice reduces carbonylation and increases expression levels of proteins involved in energy metabolism and muscle contraction. Free Radic Biol Med. 2015;82:122-136.

[31] Wineinger MA, Abresch RT, Walsh SA, Carter GT. Effects of aging and voluntary exercise on the function of dystrophic muscle from mdx mice. Am J Phys Med Rehabil. 1998;77(1):20-7.

[32] Lynch GS, Hayes A, Lam MH, Williams DA. The effects of endurance exercise on dystrophic mdx mice. II. Contractile properties of skinned muscle fibres. Proc Biol Sci. 1993;253(1336):27-33.

[33] Hayes A, Lynch GS, Williams DA. The effects of endurance exercise on dystrophic mdx mice. I. Contractile and histochemical properties of intact muscles. Proc Biol Sci. 1993;22;253(1336):19-25.

[34] Matsakas A, Yadav V, Lorca S, Narkar V. Muscle ERR $\gamma$ mitigates Duchenne muscular dystrophy via metabolic and angiogenic reprogramming. FASEB J. 2013;27(10):400416.

[35] Hayes A, Williams DA. Beneficial effects of voluntary wheel running on the properties of dystrophic mouse muscle. J Appl Physiol (1985). 1996;80(2):670-9.

[36] Call JA, Voelker KA, Wolff AV, McMillan RP, Evans NP, Hulver MW et al. Endurance capacity in maturing $m d x$ mice is markedly enhanced by combined voluntary wheel running and green tea extract. J Appl Physiol (1985). 2008;105(3):923-32.

[37] Landisch RM, Kosir AM, Nelson SA, Baltgalvis KA, Lowe DA. Adaptive and nonadaptive responses to voluntary wheel running by mdx mice. Muscle Nerve. 2008;38(4):1290-303.

[38] Call JA, McKeehen JN, Novotny SA, Lowe DA. Progressive resistance voluntary wheel running in the mdx mouse. Muscle Nerve. 2010;42(6):871-80.

[39] Baltgalvis KA, Call JA, Cochrane GD, Laker RC, Yan Z, Lowe DA. Exercise training improves plantar flexor muscle function in mdx mice. Med Sci Sports Exerc. 2012;44(9):1671-9.

[40] Gordon BS, Lowe DA, Kostek MC. Exercise increases utrophin protein expression in the $\mathrm{mdx}$ mouse model of Duchenne muscular dystrophy. Muscle Nerve. 2014;49(6):915-8. 
[41] Hourdé C, Joanne P, Medja F, Mougenot N, Jacquet A, Mouisel E, et al. Voluntary physical activity protects from susceptibility to skeletal muscle contraction-induced injury but worsens heart function in mdx mice. Am J Pathol. 2013;182(5):1509-18.

[42] Hayes A, Williams DA. Beneficial effects of voluntary wheel running on the properties of dystrophic mouse muscle. J Appl Physiol (1985). 1996;80(2):670-9.

[43] Selsby JT, Acosta P, Sleeper MM, Barton ER, Sweeney HL. Long-term wheel running compromises diaphragm function but improves cardiac and plantarflexor function in the $\mathrm{mdx}$ mouse. J Appl Physiol (1985). 2013;115(5):660-6.

[44] Dupont-Versteegden EE. Exercise and clenbuterol as strategies to decrease the progression of muscular dystrophy in mdx mice. J Appl Physiol (1985). 1996;80(3):734-41.

[45] Hulmi JJ, Oliveira BM, Silvennoinen M, Hoogaars WM, Pasternack A, Kainulainen $\mathrm{H}$ et al. Exercise restores decreased physical activity levels and increases markers of autophagy and oxidative capacity in myostatin/activinblocked mdx mice. Am J Physiol Endocrinol Metab. 2013;305(2):E171-82.

[46] Costas JM, Nye DJ, Henley JB, Plochocki JH. Voluntary exercise induces structural remodeling in the hearts of dystrophin-deficient mice. Muscle Nerve. 2010;42(6):8815 .

[47] Bueno Júnior CR, Pantaleão LC, Voltarelli VA, Bozi LH, Brum PC, Zatz M. Combined effect of AMPK/PPAR agonists and exercise training in $\mathrm{mdx}$ mice functional performance. PLoS One. 2012;7(9):e45699.

[48] Hunt LC, Anthea Coles C, Gorman CM, Tudor EM, Smythe GM, White JD. Alterations in the expression of leukemia inhibitory factor following exercise: Comparisons between wild-type and mdx muscles. PLoS Curr. 2011;3:RRN1277.

[49] Smythe GM, White JD. Voluntary wheel running in dystrophin-deficient (mdx) mice: Relationships between exercise parameters and exacerbation of the dystrophic phenotype. Version 3. PLoS Curr. 2011; [revised 2012]3:RRN1295.

[50] Brereton D, Plochocki J, An D, Costas J, Simons E. The effects of glucocorticoid and voluntary exercise treatment on the development of thoracolumbar kyphosis in dystrophindeficient mice. PLoS Curr. 2012;4:e4ffdff160de8b.

[51] Mangner N, Adams V, Sandri M, Hoellriegel R, Hambrecht $\mathrm{R}$, Schuler $\mathrm{G}$ et al. Muscle function and running activity in mouse models of hereditary muscle dystrophy: Impact of double knockout for dystrophin and the transcription factor MyoD. Muscle Nerve. 2012;45(4):544-51.

[52] Ferry A, Benchaouir R, Joanne P, Peat RA, Mougenot N, Agbulut $\mathrm{O}$, et al. Effect of voluntary physical activity initiated at age 7 months on skeletal hindlimb and cardiac muscle function in mdx mice of both genders. Muscle Nerve. 2015;52(5):788-94

[53] De Luca A, Nico B, Liantonio A, Didonna MP, Fraysse B, Pierno S, et al. A multidisciplinary evaluation of the effectiveness of cyclosporine a in dystrophic mdx mice. Am J Pathol. 2005;166(2):477-89.

[54] De Luca A, Pierno S, Liantonio A, Cetrone M, Camerino C, et al. Enhanced dystrophic progression in $\mathrm{mdx}$ mice by exercise and beneficial effects of taurine and insulin-like growth factor-1. J Pharmacol Exp Ther. 2003;304(1):453-63.

[55] Burdi R, Didonna MP, Pignol B, Nico B, Mangieri D, Rolland JF, et al. First evaluation of the potential effectiveness in muscular dystrophy of a novel chimeric compound, BN 82270 , acting as calpain-inhibitor and anti-oxidant. Neuromuscul Disord. 2006;16(4):237-48.
[56] Burdi R, Rolland JF, Fraysse B, Litvinova K, Cozzoli A, Giannuzzi V, et al. Multiple pathological events in exercised dystrophic mdx mice are targeted by pentoxifylline: Outcome of a large array of in vivo and ex vivo tests. J Appl Physiol (1985). 2009;106(4):1311-24.

[57] Fraysse B, Liantonio A, Cetrone M, Burdi R, Pierno S, Frigeri A, et al. The alteration of calcium homeostasis in adult dystrophic mdx muscle fibers is worsened by a chronic exercise in vivo. Neurobiol Dis. 2004;17(2):144-54.

[58] Faist V, König J, Höger H, Elmadfa I. Decreased mitochondrial oxygen consumption and antioxidant enzyme activities in skeletal muscle of dystrophic mice after low-intensity exercise. Ann Nutr Metab. 2001;45(2):58-66.

[59] Kaczor JJ, Hall JE, Payne E, Tarnopolsky MA. Low intensity training decreases markers of oxidative stress in skeletal muscle of mdx mice. Free Radic Biol Med. 2007;43(1):14554.

[60] Hall JE, Kaczor JJ, Hettinga BP, Isfort RJ, Tarnopolsky MA Effects of a CRF2R agonist and exercise on mdx and wildtype skeletal muscle. Muscle Nerve. 2007;36(3):336-41.

[61] van Putten M, Hulsker M, Nadarajah VD, van Heiningen SH van Huizen E, van Iterson M, et al. The effects of low levels of dystrophin on mouse muscle function and pathology. PLoS One. 2012;7(2):e31937.

[62] Camerino GM, Cannone M, Giustino A, Massari AM, Capogrosso RF, Cozzoli A, et al. Gene expression in mdx mouse muscle in relation to age and exercise: Aberrant mechanical-metabolic coupling and implications for preclinical studies in Duchenne muscular dystrophy. Hum Mol Genet. 2014;23(21):5720-32.

[63] Radley-Crabb H, Terrill J, Shavlakadze T, Tonkin J, Arthur $\mathrm{P}$, Grounds M. A single 30min treadmill exercise session is suitable for 'proof-of concept studies' in adult mdx mice: A comparison of the early consequences of two different treadmill protocols. Neuromuscul Disord. 2012;22(2):170-82.

[64] Rocco AB, Levalley JC, Eldridge JA, Marsh SA, Rodgers BD. A novel protocol for assessing exercise performance and dystropathophysiology in the $\mathrm{mdx}$ mouse. Muscle Nerve. 2014;50(4):541-8.

[65] Morales MG, Cabrera D, Céspedes C, Vio CP, Vazquez Y, Brandan $\mathrm{E}$, et al. Inhibition of the angiotensin-converting enzyme decreases skeletal muscle fibrosis in dystrophic mice by a diminution in the expression and activity of connective tissue growth factor $(\mathrm{CTGF} / \mathrm{CCN}-2)$. Cell Tissue Res. 2013;353(1):173-87.

[66] Zeman RJ, Peng H, Danon MJ, Etlinger JD. Clenbutero reduces degeneration of exercised or aged dystrophic $(\mathrm{mdx})$ muscle. Muscle Nerve. 2000;23(4):521-8.

[67] Pessina P, Cabrera D, Morales MG, Riquelme CA, Gutiérrez J, Serrano AL, et al. Novel and optimized strategies for inducing fibrosis in vivo: Focus on Duchenne Muscular Dystrophy. Skelet Muscle. 2014;4:7.

[68] Frinchi M, Macaluso F, Licciardi A, Perciavalle V, Coco M, Belluardo N, et al. Recovery of damaged skeletal muscle in mdx mice through low-intensity endurance exercise. Int $\mathbf{J}$ Sports Med. 2014;35(1):19-27.

[69] Fowler WM, Jr Abresch RT, Larson DB, Sharman RB, Entrikin RK. High-repetitive submaximal treadmill exercise training: Effect on normal and dystrophic mice. Arch Phys Med Rehabil. 1990;71(8):552-7.

[70] Anderson CL, De Repentigny Y, Cifelli C, Marshall P, Renaud JM, Worton RG, et al. The mouse dystrophin muscle promoter/enhancer drives expression of mini-dystrophin in transgenic mdx mice and rescues the dystrophy in these mice. Mol Ther. 2006;14(5):724-34. 
[71] Bizario JC, Cerri DG, Rodrigues LC, Oliveira GL, Nomizo A, de Araujo DD, et al. Imatinib mesylate ameliorates the dystrophic phenotype in exercised mdx mice. J Neuroimmunol. 2009;212(1-2):93-101.

[72] Brussee V, Tardif F, Tremblay JP. Muscle fibers of mdx mice are more vulnerable to exercise than those of normal mice. Neuromuscul Disord. 1997;7(8):487-92.

[73] Okano T, Yoshida K, Nakamura A, Sasazawa F, Oide $\mathrm{T}$, Takeda $\mathrm{S}$, et al. Chronic exercise accelerates the degeneration-regeneration cycle and downregulates insulinlike growth factor- 1 in muscle of mdx mice. Muscle Nerve. 2005;32(2):191-9.

[74] Nakamura A, Yoshida K, Ueda H, Takeda S, Ikeda S. Up-regulation of mitogen activated protein kinases in mdx skeletal muscle following chronic treadmill exercise. Biochim Biophys Acta. 2005;1740(3):326-31.

[75] Nakamura A, Yoshida K, Takeda S, Dohi N, Ikeda S. Progression of dystrophic features and activation of mitogen-activated protein kinases and calcineurin by physical exercise, in hearts of $\mathrm{mdx}$ mice. FEBS Lett. 2002;520(1-3):18-24.

[76] Kobayashi YM, Rader EP, Crawford RW, Campbell KP. Endpoint measures in the mdx mouse relevant for muscular dystrophy pre-clinical studies. Neuromuscul Disord. 2012;22(1):34-42.

[77] Taniguti AP, Pertille A, Matsumura CY, Santo Neto H, Marques MJ. Prevention of muscle fibrosis and myonecrosis in mdx mice by suramin, a TGF- $\beta 1$ blocker. Muscle Nerve. 2011;43(1):82-7.

[78] Louboutin JP, Fichter-Gagnepain V, Thaon E, Fardeau M. Morphometric analysis of mdx diaphragm muscle fibres. Comparison with hindlimb muscles. Neuromuscul Disord. 1993;3(5-6):463-9.

[79] Bostick B, Yue Y, Duan D. Gender influences cardiac function in the mdx model of Duchenne cardiomyopathy. Muscle Nerve. 2010;42(4):600-3.

[80] Kramer HF, Goodyear LJ. Exercise, MAPK, and NFkappaB signaling in skeletal muscle. J Appl Physiol (1985). 2007;103(1):388-95.

[81] Akimoto T, Pohnert SC, Li P, Zhang M, Gumbs C, Rosenberg PB, Williams RS, Yan Z. Exercise stimulates Pgc-1alpha transcription in skeletal muscle through activation of the p38 MAPK pathway. J Biol Chem. 2005;280(20):19587-93.

[82] Allen DG, Whitehead NP, Yeung EW. Mechanisms of stretch-induced muscle damage in normal and dystrophic muscle: Role of ionic changes. J Physiol. 2005;567(Pt 3):723-35.

[83] Shirokova N, Niggli E. Studies of RyR function in situ. Methods. 2008;46(3):183-93.

[84] http://www.treat-nmd.eu/research/preclinical/dmd-sops/

[85] http://www.treat-nmd.eu/downloads/file/sops/dmd/MDX/ DMD_M.2.1.001.pdf

[86] http://www.treat-nmd.eu/downloads/file/sops/dmd/MDX/ DMD_M.2.1.003.pdf

[87] Sockolov R, Irwin B, Dressendorfer RH, Bernauer EM. Exercise performance in 6-to-11-year-old boys with Duchenne muscular dystrophy. Arch Phys Med Rehabil. 1977;58(5):195-201.

[88] Pöche H, Hopfenmüller W, Hoffmann M. Detection and identification of myoglobin in serum by immunoblotting. Effect of exercise on patients with Duchenne muscular dystrophy. Clin Physiol Biochem. 1987;5(2):103-11.

[89] Barbiroli B, McCully KK, Iotti S, Lodi R, Zaniol P, Chance B. Further impairment of muscle phosphate kinetics by lengthening exercise in DMD/BMD carriers. An in vivo 31PNMR spectroscopy study. J Neurol Sci. 1993;119(1):65-73.

[90] Kemp GJ, Taylor DJ, Dunn JF, Frostick SP, Radda GK. Cellular energetics of dystrophic muscle. J Neurol Sci. 1993;116(2):201-6.

[91] Sharma KR, Mynhier MA, Miller RG. Muscular fatigue in Duchenne muscular dystrophy. Neurology. 1995;45(2):30610 .

[92] Sander M, Chavoshan B, Harris SA, Iannaccone ST, Stull JT, Thomas GD, et al. Functional muscle ischemia in neuronal nitric oxide synthase-deficient skeletal muscle of children with Duchenne muscular dystrophy. Proc Natl Acad Sci U S A. 2000;97(25):13818-23.

[93] Garrood P, Eagle M, Jardine PE, Bushby K, Straub V. Myoglobinuria in boys with Duchenne muscular dystrophy on corticosteroid therapy. Neuromuscul Disord. 2008;18(1):71-3

[94] Garrood P, Hollingsworth KG, Eagle M, Aribisala BS, Birchall D, Bushby K, et al. MR imaging in Duchenne muscular dystrophy: Quantification of T1-weighted signal, contrast uptake, and the effects of exercise. J Magn Reson Imaging. 2009;30(5):1130-8

[95] Alemdaroğlu I, Karaduman A, Yilmaz 'OT, Topaloğlu H. Different types of upper extremity exercise training in Duchenne muscular dystrophy: Effects on functional performance, strength, endurance, and ambulation. Muscle Nerve. 2015;51(5):697-705.

[96] Abramson AS, Rogoff J. Physical treatment in muscular dystrophy. Proc Second Medical Conference of Muscular Dystrophy Assoc of America. 1952;123-4

[97] de Lateur BJ, Giaconi RM. Effect on maximal strength of submaximal exercise in Duchenne muscular dystrophy. Am J Phys Med. 1979;58(1):26-36.

[98] Jansen M, van Alfen N, Geurts AC, de Groot IJ. Assisted bicycle training delays functional deterioration in boys with Duchenne muscular dystrophy: The randomized controlled trial "no use is disuse". Neurorehabil Neural Repair. 2013;27(9):816-27.

[99] Kawazoe Y, Kobayashi M, Tasaka T, Tamamoto M. Effects of therapeutic exercise on masticatory function in patients with progressive muscular dystrophy. J Neurol Neurosurg Psychiatry. 1982;45(4):343-7.

[100] Nozaki S, Kawai M, Shimoyama R, Futamura N, Matsumura $\mathrm{T}$, Adachi K, et al. Range of motion exercise of temporomandibular joint with hot pack increases occlusal force in patients with Duchenne muscular dystrophy. Acta Myol. 2010;29(3):392-7.

[101] Rodillo E, Noble-Jamieson CM, Aber V, Heckmatt JZ, Muntoni F, Dubowitz V. Respiratory muscle training in Duchenne muscular dystrophy. Arch Dis Child. 1989;64(5):736-738.

[102] Vilozni D, Bar-Yishay E, Gur I, Shapira Y, Meyer S, Godfrey $\mathrm{S}$. Computerized respiratory muscle training in children with Duchenne muscular dystrophy. Neuromuscul Disord. 1994;4(3):249-55

[103] DiMarco AF, Kelling JS, DiMarco MS, Jacobs I, Shields $\mathrm{R}$, Altose MD. The effects of inspiratory resistive training on respiratory muscle function in patients with muscular dystrophy. Muscle Nerve. 1985;8(4):284-90.

[104] Aldrich TK, Uhrlass RM. Weaning from mechanical ventilation: Successful use of modified inspiratory resistive training in muscular dystrophy. Crit Care Med. 1987;15(3):2479

[105] Topin N, Matecki S, Le Bris S, Rivier F, Echenne B, Prefaut $\mathrm{C}$, et al. Dose-dependent effect of individualized respiratory 
muscle training in children with Duchenne muscular dystrophy. Neuromuscul Disord. 2002;12(6):576-83.

[106] Wanke T, Toifl K, Merkle M, Formanek D, Lahrmann $\mathrm{H}$, Zwick $\mathrm{H}$. Inspiratory muscle training in patients with Duchenne muscular dystrophy. Chest. 1994;105(2):475-82.

[107] Gozal D, Thiriet P. Respiratory muscle training in neuromuscular disease: Long-term effects on strength and load perception. Med Sci Sports Exerc. 1999;31(11):1522-7.

[108] Winkler G, Zifko U, Nader A, Frank W, Zwick H, Toifl K, et al. Dose-dependent effects of inspiratory muscle training in neuromuscular disorders. Muscle Nerve. 2000;23(8):125760.

[109] Rodrigues MR, Carvalho CR, Santaella DF, Lorenzi-Filho G, Marie SK. Effects of yoga breathing exercises on pulmonary function in patients with Duchenne muscular dystrophy: An exploratory analysis. J Bras Pneumol. 2014;40(2):128-33.
[110] Koessler W, Wanke T, Winkler G, Nader A, Toifl K, Kurz H, et al. 2 Years' experience with inspiratory muscle training in patients with neuromuscular disorders. Chest. 2001;120(3):765-9.

[111] http://www.nchpad.org/119/928/Duchenne Muscular Dystrophy

[112] http://support.cureduchenne.org/site/PageServer?pagename =aug2014page 11

[113] Gianola S, Pecoraro V, Lambiase S, Gatti R, Banfi G, Moja L. Efficacy of muscle exercise in patients with muscular dystrophy: A systematic review showing a missed opportunity to improve outcomes. PLoS One. 2013;8(6):e65414.

[114] Duchenne GBA. Recherches sur la paralysie musculaire pseudo-hypertrophique ou paralysie myo-sclerosique. Arch Gen Med. 1868;11:5-25. 